\title{
Eksplorasi Plasma Nutfah Jagung Manado Kuning di Sulawesi Utara (The Exploration of Manadonese Yellow Maize Germplasm inNorth Sulawesi)
}

\author{
Semuel D. Runtunuwu ${ }^{1)^{*}}$, Y. Pamandungan ${ }^{1)}$, dan R. Mamarimbing ${ }^{1)}$ \\ 1) Jurusan Budidaya Fak. Pertanian, Kampus Unsrat Kleak Manado 95115 \\ *Alamat korespondensi: semueldr@gmail.com
}

Diterima 15 Juli 2014, diterima untuk dipublikasikan 15 Agustus 2014

\begin{abstract}
Abstrak
Penelitian ini bertujuan untuk mengoleksi dan mengevaluasi jagung Manado Kuning berdasarkan karakter morfologi tongkol dan biji. Penelitian dilaksanakan dalam dua tahap, yaitu eksplorasi untuk mengoleksi tongkol jagung Manado Kuning dan evaluasi aksesi jagung Manado Kuning berdasarkan karakter morfologi tongkol dan biji. Eksplorasi dilaksanakan pada akhir bulan Agustus 2013 sampai dengan bulan Desember 2013 di sentra produksi. Sentra produksi adalah daerah yang diketahui secara tradisi menanam jagung Manado Kuning dan daerah yang menggunakan jagung sebagai makanan pokok. Penentuan desa dilakukan bekerjasama dengan Dinas Pertanian Provinsi Sulawesi Utara dan petugas penyuluh lapangan kabupaten/kota. Hasil koleksi berupa tongkol dibuatkan data paspornya. Karakter morfologi yang diamati meliputi susunan baris dan jumlah baris biji, serta warna dan bentuk biji. Analisis data dilakukan menggunakan Program Software SPSS untuk mengelompokkan aksesi jagung. Eksplorasi menghasilkan 28 aksesi. Berdasarkan evaluasi karakter morfologi tongkol dan biji, pada kesamaan genetik 75 \% terdapat 2 kelompok jagung Manado Kuning. Kelompok I terdiri dari 6 aksesi dan kelompok II terdiri dari 22 aksesi. Sesuai dengan deskripsi awal, jagung Manado Kuning dengan karakter biji berwarna kuning dengan tipe biji flint mengelompok sendiri pada kesamaan genetik sekitar $95 \%$, yaitu kelompok IV yang terdiri dari 13 aksesi.

Kata kunci: eksplorasi, karakterisasi, aksesi, jagung Manado Kuning
\end{abstract}

\begin{abstract}
The purpose of this study was to collect and evaluate Manadonese yellow corn cobs and grain based on the morphological characteristics. The study was carried out in two stages, i.e. the exploration for collecting corn cobs Manado Yellow and the evaluation of accession Manadonese yellow corn based on cobs and grain morphological characteristics. The exploration was conducted between late August 2013 and December 2013 in the production centre. The production centre is the area that is traditionally planted corn yellow Manado and the area that used corn as the staple food. The determination of the location was carried out in collaboration with the Department of Agriculture of North Sulawesi and the district/city extension agents. The passport data was made of the results of the cobs data collection. The evaluated morphological characteristics included the arrangement and the number of the seed row, the color and type of seeds. The data was analyzed using SPSS software program to group maize accessions. The exploration resulted in 28 accessions. Based on the morphological characterization of cobs and seeds at the genetic similarity of $75 \%$, there were 2 groups of Manadonese yellow corn. Group I consisted of 6 accessions and group II consisted of 22 accessions. The same as in the initial description, Manadonese yellow corn with flint grain type was grouped itself in 95\% genetic similarity, i.e. the group IV that was consisted of 13 accessions.

Kata kunci: accession, characterization, exploration, yellow Manadonese corn
\end{abstract}




\section{PENDAHULUAN}

Sejak abad ke-16 petani di berbagai daerah mulai membudidayakan jagung dan melakukan seleksi sesuai dengan keinginannya dalam areal yang sempit. Lambat laun muncul varietas lokal dan beradaptasi dengan baik di daerah masing-masing, sehingga terbentuklah varietas lokal (landraces) (Budiarti 2007), yaitu jenis jagung yang terkonservasi di alam dalam kurun waktu yang panjang di lokasi tertentu karena memiliki daya adaptasi yang tinggi terhadap lingkungan selain itu terdapat karakter yang unik dan disenangi petani (Faesal dan Suryawati 2011).

Jagung Manado Kuning merupakan salah satu varietas unggul lokal asal Manado, golongan bersari bebas, umur $50 \%$ keluar rambut 60 hari, umur panen 105 - 110 hari, warna biji kuning, tipe biji mutiara (flint), tidak tahan bulai (Sclerospora maydis), dan sudah dilepas sebelum tahun 1945 (Hermanto et al. 2009). Walaupun sudah lama dilepas, namun petani di daerah ini (terutama di daerah $\mathrm{Kec}$. Tompaso, Kec. Kawangkoan, Kec. Langoan) masih banyak menanam jagung Manado Kuning karena ternyata jagung ini lebih disukai ternak, seperti kuda dan sapi, dibandingkan dengan jagung Hibrida (Runtunuwu 2006). Oleh karena itu Jagung Manado Kuning perlu dipertahankan sebagai plasma nutfah seiring dengan semakin intensifnya penggunaan jagung sebagai bahan pakan ternak.

Salah satu permasalahan pengembangan jagung komposit, termasuk jagung Manado Kuning adalah sistem perbenihan yang belum berkembang (Hidajat 2009). Umumnya petani di daerah ini mengambil benih dari hasil panen sebelumnya tanpa melalui proses seleksi yang baik (Managanta 2008). Di samping itu, seiring dengan berkembangnya penanaman jagung hibrida di daerah ini maka jagung Manado Kuning ditanam berdekatan dengan jagung hibrida, yang bisa menyebabkan terjadi persilangan secara alami antara kedua jagung tersebut. Hal ini bisa menyebabkan jagung Manado Kuning yang dikembangkan petani dewasa ini sudah sangat beragam satu daerah dengan daerah lainnya. Oleh karena itu perlu dilakukan eksplorasi jagung Manado Kuning di Minahasa dan sekitarnya. Eksplorasi merupakan kegiatan pencarian bahan-bahan genetik tanaman, berupa genotipe-genotipe, kultivar, klon tanaman, dari alam seperti pertanaman yang ada pada petani atau dari koleksi laboratorium atau perorangan (Yusuf 2005).

Tujuan eksplorasi ini adalah untuk mengoleksi dan mengevaluasi jagung Manado Kuning berdasarkan karakter morfologi tongkol dan biji. Dengan terdatanya Jagung Manado Kuning ini, maka akan menjadi informasi yang dapat digunakan oleh para pemulia tanaman dalam merakit varietas unggul baru.

\section{METODE PENELITIAN}

Eksplorasi jagung Manado Kuning ini dilaksanakan dua tahap. Tahap I adalah eksplorasi untuk mengoleksi jagung Manado Kuning dalam bentuk tongkol dan tahap II ialah evaluasi aksesi jagung Manado Kuning untuk mengelompokkan aksesi jagung Manado Kuning hasil eksplorasi berdasarkan morfologi tongkol dan biji.

Eksplorasi dilaksanakan pada akhir bulan Agustus 2013 sampai dengan bulan Desember 2013, di Kabupaten Minahasa (daerah asal jagung ini) dan di beberapa kabupaten sekitarnya, Kabupaten sekitarnya yang dimaksud ialah Kabupaten Bolaang Mongondow (Bolmong), Kabupaten Bolaang Mongondouw Utara (Bolmut), Kabupaten Bolaang Mongondow Selatan (Bolsel), Kabupaten Bolaang Mongondow Timur (Boltim), Kota Kotamobagu, Kabupaten Minahasa 
Selatan (Minsel), Kabupaten Minahasa Utara (Minut), Kabupaten Minahasa Tenggara (Mitra), dan Kota Tomohon.

Eksplorasi dilakukan di sentra produksi, daerah yang diketahui secara tradisi menanam jagung Manado Kuning, dan daerah yang menggunakan jagung sebagai makanan pokok. Penentuan lokasi eksplorasi dilakukan bekerjasama dengan instansi terkait, yaitu Dinas Pertanian Provinsi Sulawesi Utara, selanjutnya Kabupaten/Kota dan Petugas Penyuluh Lapangan. Setelah informasi lokasi diketahui, tim mendatangi langsung lokasi tempat tumbuh tanaman ini untuk membuat data paspor, yaitu tanggal koleksi, lokasi (desa, kecamatan, dan kabupaten), letak lintang dan bujur, ketinggian tempat, dan sumber koleksi (lahan petani, rumah tangga petani, pasar tradisional, dan lain-lain). Karakter morfologi tongkol dan biji yang dievaluasi meliputi susunan baris biji dan jumlah baris, serta warna dan tipe biji. Data karakter morfologi tongkol dan biji diskoring sesuai Panduan Karakterisasi Tanaman Pangan (2014), selanjutnya dianalisis menggunakan Program Software SPSS untuk mengelompokan antar aksesi jagung Manado Kuning.

\section{HASIL DAN PEMBAHASAN Aksesi Jagung Manado Kuning} Hasil koleksi berdasarkan kabupaten/desa, aksesi dan kegunaan seperti disajikan pada Tabel 1. Koleksi dilakukan umumnya langsung dari ladang dan hanya 3 lokasi yang dikoleksi dari gudang penyimpanan, yaitu tongkol sudah disimpan untuk dijadikan benih pada musim tanam berikutnya, yaitu lokasi Durian, Tawaang dan Tompaso.

Tabel 1. Hasil Eksplorasi Jagung Manado Kuning

\begin{tabular}{|c|c|c|c|c|}
\hline Kabupaten/Desa & $\begin{array}{l}\text { Jumlah } \\
\text { Aksesi }\end{array}$ & Aksesi & Kegunaan & $\begin{array}{l}\text { Sumber } \\
\text { Koleksi }\end{array}$ \\
\hline \multicolumn{5}{|l|}{ Minahasa Selatan } \\
\hline Durian & 2 & SR-1, SR-2 & Butir, Pangan & $\begin{array}{l}\text { Gudang } \\
\text { penyimpanan }\end{array}$ \\
\hline Tawaang & 2 & YP-1, YP-2 & Butir, Tepung & $\begin{array}{l}\text { Gudang } \\
\text { penyimpanan }\end{array}$ \\
\hline Sapa & 2 & $\mathrm{RM}-1, \mathrm{RM}-2$ & Butir & Ladang \\
\hline \multicolumn{5}{|l|}{ Minahasa } \\
\hline Tountimomor & 2 & YP-3, YP-4 & Butir & Ladang \\
\hline Parentek & 3 & $\begin{array}{l}\text { SR-3, SR-4, SR- } \\
5\end{array}$ & Butir & Ladang \\
\hline Tondegesan & 2 & $\mathrm{RM}-3, \mathrm{RM}-4$ & Butir & Ladang \\
\hline Tompaso & 2 & SR-6, SR-7 & $\begin{array}{l}\text { Butir, Pakan dlm } \\
\text { bentuk jerami }\end{array}$ & $\begin{array}{l}\text { Gudang } \\
\text { penyimpanan }\end{array}$ \\
\hline Tombulu & 2 & YP-5, YP-6 & Butir & Ladang \\
\hline Kembes & 1 & RM-5 & Butir & Ladang \\
\hline \multicolumn{5}{|l|}{ Minahasa Utara } \\
\hline Tontalete & 2 & YP-7, YP-8 & Butir & Ladang \\
\hline \multicolumn{5}{|l|}{ Tomohon } \\
\hline Tara-tara & 2 & YP-9, YP-10 & Butir & Ladang \\
\hline Ranotongkor & 2 & YP-11, YP-12 & Butir & Ladang \\
\hline \multicolumn{5}{|l|}{ Kotamobagu } \\
\hline Lobong & 2 & SR-8, SR-9 & Butir, Pangan & Ladang \\
\hline \multicolumn{5}{|l|}{ Bolmong } \\
\hline Lolak & 2 & SR-10, SR-11 & Butir, Pangan & Ladang \\
\hline Total & 28 & - & - & \\
\hline
\end{tabular}

Keterangan: $\mathrm{SR}=$ Semuel D. Runtunuwu, $\mathrm{YP}=$ Yefta Pamandungan, $\mathrm{RM}=$ Rinny Mamarimbing. 
Runtunuwu dkk, Eksplorasi plasma ... 59

Berdasarkan data pada Tabel 1, maka telah berhasil dikoleksi sebanyak 28 aksesi jagung Manado Kuning, belum termasuk Kab. Bolsel, Kab. Bolmut, Kab. Boltim, dan Kab. Mitra karena pada saat eksplorasi dilakukan ternyata petani sudah beralih menanam jagung hibrida karena produksinya lebih tinggi atau pada saat eksplorasi dilakukan tanaman masih muda (belum saat panen).

Pada saat eksplorasi, menurut petani jagung Manado Kuning ditanam untuk dimanfaatkan sebagai: 1) Butir, 2) Tepung, 3) Pakan dalam bentuk jerami, dan 4) Pangan. Khusus daerah Tompaso, karena daerah ini banyak ternak kuda pacu maka hasil jagung Manado Kuning, selain dimanfaatkan dalam bentuk biji, tapi dimanfaatkan juga dalam bentuk jerami.
Lokasi koleksi jagung Manado Kuning terletak antara ketinggian dari muka laut berkisar dari 10 sampai 600 $\mathrm{m}$, dengan Latitude (letak lintang) $00^{\circ} 54^{\prime} 05,4^{\prime \prime}$ sampai $01^{0} 24^{\prime} 86,3$ " dan $124^{\circ} 03^{\prime} 03,8^{\prime \prime} \quad$ sampai $125^{\circ} 04^{\prime} 17,1^{\prime \prime}$ (Tabel 2).

\section{Morfologi Tongkol}

Evaluasi morfologi tongkol dilakukan berdasarkan susunan baris biji dan jumlah baris biji per tongkol. Menurut Komisi Nasional Plasma Nutfah (2004), terdapat empat tipe susunan baris biji jagung yaitu: 1) Teratur, 2) Tidak teratur, 3) Lurus, dan 4) Melengkung (Gambar 1). Sedangkan Jumlah baris biji, dihitung jumlah baris biji di bagian tengah pada tongkol paling atas. Hasil evaluasi morfologi tongkol keduapuluhdelapan aksesi jagung Manado Kuning disajikan pada Tabel 3.

Tabel 2. Latituda dan Altituda Lokasi Eksplorasi Jagung Manado Kuning

\begin{tabular}{|c|c|c|c|c|}
\hline \multirow{2}{*}{ Kabupaten/Desa } & \multirow{2}{*}{ Aksesi } & \multicolumn{2}{|c|}{ Latituda } & \multirow{2}{*}{$\begin{array}{l}\text { Altituda } \\
\text { (m dpl) }\end{array}$} \\
\hline & & Utara & Selatan & \\
\hline \multicolumn{5}{|l|}{ Minahasa Selatan } \\
\hline Durian & SR-1, SR-2 & $01^{\circ} 00^{\prime} 49,0^{\prime \prime}$ & $124^{\circ} 8^{\prime} 69,4^{\prime \prime}$ & 15 \\
\hline Tawaang & YP-1, YP-2 & $01^{\circ} 10^{\prime} 27,4^{\prime \prime}$ & $124^{\circ} 28^{\prime} 04,9^{\prime \prime}$ & 13 \\
\hline Sapa & RM-1, RM-2 & $01^{\circ} 09^{\prime} 76,9^{\prime \prime}$ & $124^{\circ} 21^{\prime} 21,7^{\prime \prime}$ & 18 \\
\hline \multicolumn{5}{|l|}{ Minahasa } \\
\hline Tountimomor & YP-3, YP-4 & $01^{\circ} 11^{\prime} 17,6 "$ & $124^{\circ} 51^{\prime} 14,5^{\prime \prime}$ & 500 \\
\hline Parentek & SR-3, SR-4, SR-5 & $01^{\circ} 08^{\prime} 10,8^{\prime \prime}$ & $125^{\circ} 00^{\prime} 74,2 \prime$ & 16 \\
\hline Tondegesan & $\mathrm{RM}-3, \mathrm{RM}-4$ & $01^{\circ} 12^{\prime} 06,1^{\prime \prime}$ & $124^{\circ} 48^{\prime} 93,2 "$ & 500 \\
\hline Tompaso & SR-6, SR-7 & $01^{\circ} 10^{\prime} 62,6^{\prime \prime}$ & $124^{\circ} 48^{\prime} 33,3^{\prime \prime}$ & 500 \\
\hline Tombulu & YP-5, YP-6 & $01^{\circ} 24^{\prime} 86,3^{\prime \prime}$ & $124^{\circ} 53^{\prime} 27,5^{\prime \prime}$ & 70 \\
\hline Kembes & RM-5 & $01^{\circ} 23 " 73,1 "$ & $124^{\circ} 53^{\prime} 80,4^{\prime \prime}$ & 70 \\
\hline \multicolumn{5}{|l|}{ Minahasa Utara } \\
\hline Tontalete & YP-7, YP-8 & $01^{\circ} 22 " 50,0 "$ & $125^{\circ} 04^{\prime} 17,1^{\prime \prime}$ & 108 \\
\hline \multicolumn{5}{|l|}{ Tomohon } \\
\hline Tara-tara & YP-9, YP-10 & $01^{\circ} 20^{\prime \prime} 03,5^{\prime \prime}$ & $124^{\circ} 44^{\prime} 30,6^{\prime \prime}$ & 600 \\
\hline Ranotongkor & YP-11, YP-12 & $01^{\circ} 20 " 04,5 "$ & $124^{\circ} 44^{\prime} 32,6^{\prime \prime}$ & 300 \\
\hline \multicolumn{5}{|l|}{ Kotamobagu } \\
\hline Lobong & SR-8, SR-9 & $00^{\circ} 77^{\prime} 77,7^{\prime \prime}$ & $124^{\circ} 25^{\prime} 51,7^{\prime \prime}$ & 201 \\
\hline \multicolumn{5}{|l|}{ Bolmong } \\
\hline Lolak & SR-10, SR-11 & $00^{0} 54^{\prime} 05,4^{\prime \prime}$ & $124^{0} 03^{\prime} 03,8^{\prime \prime}$ & 165 \\
\hline
\end{tabular}




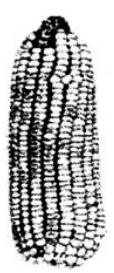

1

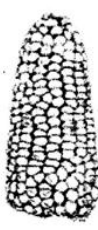

2

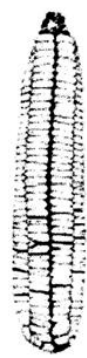

3

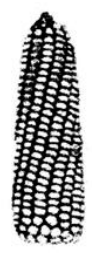

4

Gambar 1. Susunan Baris Biji Jagung.

1.Teratur, 2. Tidak teratur, 3. Lurus, dan 4. Melengkung (Komisi Nasional Plasma Nutfah. 2004).

Tabel 3. Evaluasi Tongkol Hasil Eksplorasi Jagung Manado Kuning

\begin{tabular}{|c|c|c|c|}
\hline Kabupaten/Desa & Aksesi & $\begin{array}{c}\text { Susunan Baris } \\
\text { Biji }\end{array}$ & $\begin{array}{c}\text { Jumlah } \\
\text { Baris Biji }\end{array}$ \\
\hline \multicolumn{4}{|l|}{ Minahasa Selatan } \\
\hline \multirow{2}{*}{ Durian } & SR-1 & Lurus & 12 \\
\hline & SR-2 & Melengkung & 12 \\
\hline \multirow{2}{*}{ Tawaang } & YP-1 & Teratur & 14 \\
\hline & YP-2 & Lurus & 12 \\
\hline \multirow{2}{*}{ Sapa } & RM-1 & Tidak Teratur & 12 \\
\hline & RM-2 & Teratur & 12 \\
\hline \multicolumn{4}{|l|}{ Minahasa } \\
\hline \multirow{3}{*}{ Tountimomor } & YP-3 & Teratur & 12 \\
\hline & YP-4 & Teratur & 14 \\
\hline & SR-3 & Tidak Teratur & 12 \\
\hline \multirow[t]{2}{*}{ Parentek } & SR-4 & Teratur & 12 \\
\hline & SR-5 & Lurus & 12 \\
\hline \multirow{2}{*}{ Tondegesan } & RM-3 & Melengkung & 10 \\
\hline & RM-4 & Teratur & 10 \\
\hline \multirow{2}{*}{ Tompaso } & SR-6 & Melengkung & 10 \\
\hline & SR-7 & Lurus & 12 \\
\hline \multirow{2}{*}{ Tombulu } & YP-5 & Lurus & 10 \\
\hline & YP-6 & Teratur & 10 \\
\hline Kembes & RM-5 & Lurus & 12 \\
\hline \multicolumn{4}{|l|}{ Minahasa Utara } \\
\hline \multirow{2}{*}{ Tontalete } & YP-7 & Lurus & 12 \\
\hline & YP-8 & Teratur & 10 \\
\hline \multicolumn{4}{|l|}{ Tomohon } \\
\hline \multirow{2}{*}{ Tara-tara } & YP-9 & Lurus & 12 \\
\hline & YP-10 & Lurus & 10 \\
\hline \multirow{2}{*}{ Ranotongkor } & YP-11 & Lurus & 12 \\
\hline & YP-12 & Teratur & 14 \\
\hline \multicolumn{4}{|l|}{ Kotamobagu } \\
\hline \multirow{2}{*}{ Lobong } & SR-8 & Lurus & 10 \\
\hline & SR-9 & Lurus & 14 \\
\hline \multicolumn{4}{|l|}{ Bolmong } \\
\hline \multirow[b]{2}{*}{ Lolak } & SR-10 & Teratur & 12 \\
\hline & SR-11 & Teratur & 12 \\
\hline
\end{tabular}


Berdasarkan hasil evaluasi morfologi tongkol (Tabel 3), susunan baris biji keduapuluhdelapan aksesi jagung Manado Kuning beragam, dari teratur sampai melengkung, dengan jumlah baris biji berkisar dari 10 sampai 14 baris.

\section{Morfologi Biji}

Hasil evaluasi keduapuluhdelapan aksesi jagung Manado Kuning berdasarkan tipe dan warna biji disajikan pada Tabel 4. Jagung Manado Kuning yang ditanam petani ada dua tipe biji, yaitu flint dan dent, dengan dua warna biji, yaitu kuning dan kuning oranye.

Berdasarkan analisis kluster sesuai data karakter morfologi tongkol dan biji, jagung Manado Kuning yang ditanam petani pada saat ini, pada kesamaan genetik $75 \%$ terdapat dua kelompok besar, yaitu kelompok I terdiri dari 6 aksesi dan kelompok II terdiri dari 22 aksesi. kelompok I terdiri dari aksesi RM-2, SR-11, YP-6, YP-8, YP10, SR-2, dan RM-3, sedangkan kelompok II terdiri dari aksesi RM-3,SR6,SR-8, YP-4,YP-12, YP-2, SR-4, YP1, SR-9, YP-9, YP-11, SR-1, RM-5, YP-7, SR-5, SR-7, YP-3, SR-10, RM-1, SR-3, RM-4, dan YP-5 (Gambar 2). Pada kesamaan genetik ini, kelompok I terdiri dari aksesi biji jagung tipe flint berwarna kuning orange, sedangkan kelompok II terdiri dari aksesi biji jagung warna kuning dengan tipe flint dan dent (Tabel 3). Jagung Manado Kuning sesuai dengan deskripsi awal, yaitu biji berwarna kuning tipe flint mengelompok sendiri pada kesamaan genetik sekitar $95 \%$, yaitu kelompok III, yang terdiri dari 15 aksesi (YP-1, SR-9, YP-9, YP11, SR-1, RM-5, YP-7, SR-5, SR-7, YP3, SR-10, RM-1, SR-3, RM-4 dan YP-5).

Berdasarkan data pada Tabel 3, kelimabelas aksesi jagung Manado
Kuning tersebut mempunyai susunan baris biji dan jumlah baris biji yang beragam. Aksesi dengan susunan baris biji lurus sebanyak 9 aksesi (SR-1, SR5, SR-7, YP-5, RM-5, YP-7, YP-9, YP11, SR-9), teratur sebanyak 4 aksesi (YP-1, YP-3, RM-4, SR-10), dan tidak teratur sebanyak 2 aksesi (RM-1, SR-3).

Selanjutnya, kelimabelas aksesi jagung Manado Kuning (kelompok III) perlu dikarakterisasi lebih lanjut dan dilakukan permurnian genetik untuk produksi benih karena dengan semakin berkembangnya varietas unggul yang telah dilepas dan menyebar luas, maka varietas lokal seperti jagung Manado Kuning perlu dilestarikan agar selalu tersedia sumber gen untuk masa kini maupun masa mendatang (Sutoro dan Zuraida 2007). Menurut Yasin et al. (2007) jagung Manado Kuning mengandung protein dan lemak yang cukup tinggi, yaitu $9,44 \%$ dan $5,01 \%$. Menurut Langoy (2012) nilai nutrisi jerami jagung Manado Kuning yang difermentasi dengan effective microorganism (EM4) lebih tinggi dibandingkan dengan jerami jagung hibrida. Protein kasar dan energi jagung Manado Kuning lebih tinggi dibandingkan dengan jagung Hibrida Bisi-2, yaitu berturut $7,49 \%$ dan $264,80 \%$ dibandingkan dengan 4,84\% dan $247,48 \%$. Serat kasar jagung Manado Kuning lebih rendah $(22,11 \%)$ dibandingkan dengan jagung Hibrida Bisi-2 (26,74\%). Lebih rendahnya kandungan serat kasar jagung Manado Kuning ini menyebabkan jerami jagung ini akan lebih mudah dicerna oleh ternak. Produksi benih jagung Manado Kuning memungkinkan dilakukan di daerah ini karena menurut Bahtiar, et al. (2010) KP. Pandu memenuhi persyaratan lokasi untuk usaha produksi benih komposit (termasuk Manado Kuning). 
62 JURNAL BIOSLOGOS, AGUSTUS 2014, VOL. 4 NOMOR 2

Tabel 4. Evaluasi Biji Hasil Eksplorasi Jagung Manado Kuning

\begin{tabular}{|c|c|c|c|}
\hline Kabupaten/Desa & Aksesi & Tipe Biji & Warna Bbiji \\
\hline \multicolumn{4}{|l|}{ Minahasa Selatan } \\
\hline \multirow{2}{*}{ Durian } & SR-1 & Flint & Kuning \\
\hline & SR-2 & Flint & Kuning oranye \\
\hline \multirow{2}{*}{ Tawaang } & YP-1 & Flint & Kuning \\
\hline & YP-2 & Dent & Kuning \\
\hline \multirow{2}{*}{ Sapa } & RM-1 & Flint & Kuning \\
\hline & RM-2 & Flint & Kuning oranye \\
\hline \multicolumn{4}{|l|}{ Minahasa } \\
\hline \multirow{3}{*}{ Tountimomor } & YP-3 & Flint & Kuning \\
\hline & YP-4 & Dent & Kuning \\
\hline & SR-3 & Flint & Kuning \\
\hline \multirow[t]{2}{*}{ Parentek } & SR-4 & Dent & Kuning \\
\hline & SR-5 & Flint & Kuning \\
\hline \multirow{2}{*}{ Tondegesan } & RM-3 & Dent & Kuning \\
\hline & RM-4 & Flint & Kuning \\
\hline \multirow{2}{*}{ Tompaso } & SR-6 & Dent & Kuning \\
\hline & SR-7 & Flint & Kuning \\
\hline \multirow{2}{*}{ Tombulu } & YP-5 & Flint & Kuning \\
\hline & YP-6 & Flint & Kuning oranye \\
\hline Kembes & RM-5 & Flint & Kuning \\
\hline \multicolumn{4}{|l|}{ Minahasa Utara } \\
\hline \multirow{2}{*}{ Tontalete } & YP-7 & Flint & Kuning \\
\hline & YP-8 & Flint & Kuning oranye \\
\hline \multicolumn{4}{|l|}{ Tomohon } \\
\hline \multirow{2}{*}{ Tara-tara } & YP-9 & Flint & Kuning \\
\hline & YP-10 & Flint & Kuning oranye \\
\hline \multirow{2}{*}{ Ranotongkor } & YP-11 & Flint & Kuning \\
\hline & YP-12 & Dent & Kuning \\
\hline \multicolumn{4}{|l|}{ Kotamobagu } \\
\hline \multirow{2}{*}{ Lobong } & SR-8 & Dent & Kuning \\
\hline & SR-9 & Flint & Kuning \\
\hline \multicolumn{4}{|l|}{ Bolmong } \\
\hline \multirow{2}{*}{ Lolak } & SR-10 & Flint & Kuning \\
\hline & SR-11 & Flint & Kuning oranye \\
\hline
\end{tabular}




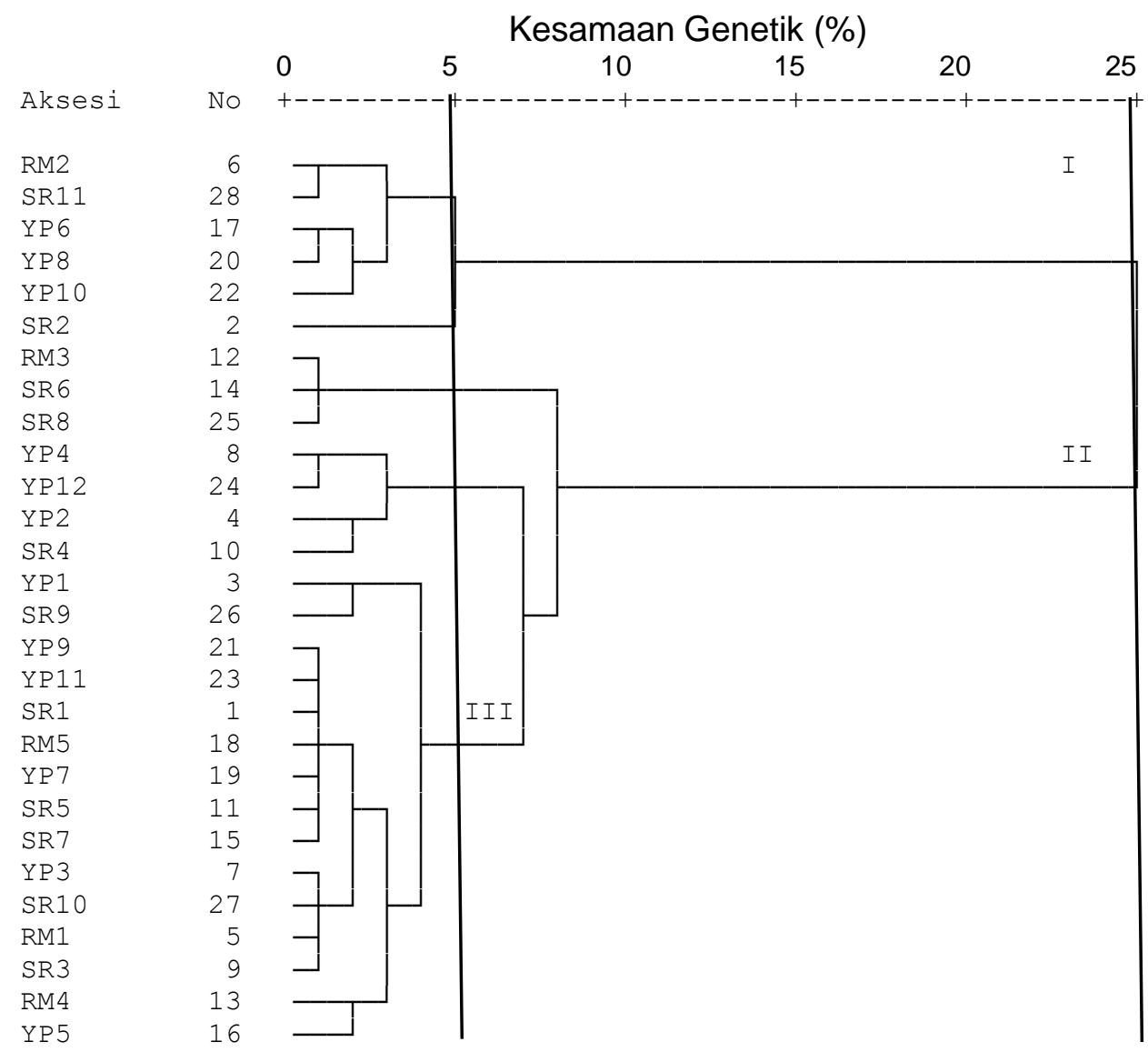

Gambar 2. Pengelompokan aksesi jagung Manado Kuning berdasarkan morfologi tongkol dan biji.

Hasil evaluasi ini menunjukan bahwa jagung Manado Kuning yang ditanam oleh petani di daerah ini sudah beragam. Hal ini sangat mungkin terjadi karena menurut Yusuf (2005), di alam akan terjadi proses evolusi yang akan memunculkan genotipe-genotipe baru. Hibridisasi alami, mutasi, dan seleksi alam akan merupakan kekuatan di alam yang mendorong munculnya genotipegenotipe baru yang unggul dalam arti mampu beradaptasi terhadap tekanantekanan lingkungan, seperti hama, penyakit, atau kekeringan. Oleh sebab itu sangat penting melakukan eksplorasi secara beraturan untuk menjaring genotipe baru, baik genotipe yang belum terjaring oleh eksplorasi sebelumnya atau mutan baru yang secara periodik selalu muncul di alam. Pemunculan genotipe-genotipe baru di alam mungkin terjadi karena menurut Dahlan (1998) satu malai dapat menghasilkan jutaan tepung sari yang dapat diterbangkan angin. Malai mulai menghasilkan tepung sari 1 - 3 hari lebih dahulu daripada keluarnya rambut tongkol. Dengan demikian peluang terjadinya penyerbukan silang mencapai $95 \%$ atau lebih.

\section{KESIMPULAN}

Eksplorasi jagung Manado Kuning di Kabupaten Minahasa dan sekitarnya menghasilkan 28 aksesi. Berdasarkan karakter morfologi tongkol dan biji, jagung Manado Kuning yang ditanam oleh petani di daerah ini sudah sangat 
beragam dan ari keduapuluhdelapan aksesi yang berhasil dikoleksi, hanya 15 diantaranya yang sesuai dengan deskripsi jagung Manado Kuning, yaitu biji berwarna kuning, dengan tipe biji flint.

\section{UCAPAN TERIMA KASIH}

Penelitian ini dibiayai oleh Pemerintah Provinsi Sulawesi Utara Tahun Anggaran 2013 melalui Dinas Pertanian dan Peternakan Prov. Sulut.

\section{DAFTAR PUSTAKA}

Budiarti SG (2007) Status pengelolaan plasma nutfah jagung. Buletin Plasma Nutfah 13 (1): 11 - 18

Bahtiar, Rembang JW, Tenrirawe A (2010) Prospek produksi benih sumber jagung komposit di Provinsi Sulawesi Utara. Prosiding Pekan Serealia Nasional. pp $574-580$

Dahlan M (1998) Pembentukan dan produksi benih varietas bersari bebas. Balai Penelitian Tanaman Pangan. Malang

Faesal, Suryawati (2011) Urgensi plasma nutfah jagung lokal di Flores Nusa Tenggara Timur. Balai Penelitian Tanaman Serealia. $7 \mathrm{Hal}$

Hermanto DW, Sadikin E, Hikmat (2009) Deskripsi varietas unggul palawija 1918 -2009. Puslitbangtan Pangan. Balitbang Pertanian

Hidajat JR (2009) Perkembangan perbenihan jagung. Risalah Seminar Penelitian dan Pengembangan Tanaman Pangan 2007-2008. Balitbang
Pertanian. Puslitbang Tanaman Pangan. pp 201-209

Komisi Nasional Plasma Nutfah (2004) Panduan Karakterisasi Tanaman Pangan: Jagung dan Sorgum. Balitbang. Deptan.

Langoy W (2012) Nilai nutrisi jerami jagung varietas Hibrida Bisi-2 dan Manado Kuning yang difermentasi dengan effective microorganisms (EM4). Tesis. Program Pascasarjana Unsrat. Manado.

Managanta A (2008) Penerapan metode seleksi massa dalam upaya peningkatan produktivitas var. jagung Manado Kuning. Skripsi. Fakultas Pertanian Unsrat Manado

Runtunuwu S D (2006) Manado Kuning, jagung berjasa yang ditinggalkan dalam crash program jagung. Harian Komentar edisi 18 Desember 2006.

Sutoro, Zuraida N (2007) Pengelolaan plasma nutfah jagung. Jagung: Teknik Produksi dan Pengembangan. Puslitbang Tanaman Pangan. Bogor. pp 2941

Yasin MHG, Singgih S, Hamdani M, Sigit B Santoso (2007) Keragaman hayati plasma nutfah jagung. Jagung: Teknik Produksi dan Pengembangan. Puslitbang Tanaman Pangan. Bogor. pp 4245

Yusuf M (2005) Metode eksplorasi, inventarisasi, evaluasi dan konservasi plasmanutfah. Indoplasma.co.id/artikel_2005_m otode_eksplorasi.htm. 